\title{
Numerical simulations and statistics of surges in the White and Barents seas
}

\author{
A. D. Korablina ${ }^{1}$, A. T. Kondrin ${ }^{1}$, and V. S. Arkhipkin ${ }^{1}$ \\ Received 22 November 2017; accepted 22 November 2017; published 7 December 2017.
}

Numerical simulation of surges in the White and Barents seas is based on the ADCIRC numerical model and SWAN spectral wave model. In this paper, the terms "surge" and "storm surge" were divided. The "surge" is considered to be a physical phenomenon, and "storm surge" is an eco-geographical one. A calculating method of surge height was presented. Calculations were made using an unstructured mesh with high spatial resolution, covering both the White and Barents seas with a minimum step of $50 \mathrm{~m}$ in the coastal zone. The NCEP/CFSR reanalysis of wind, atmospheric pressure, and ice concentration fields from 1979 to 2015 were used as the input data. The tides based on the FES 2008 database with a $1 / 8^{\circ}$ resolution were defined at the open boundary. Validation of the ADCIRC model data was made using the observational data. The ADCIRC model was adjusted to the conditions in the White and Barents seas. The synoptic situations, which lead to surge occurrence, were analyzed. The seasonal and interannual variability of the occurrence of surges was given. The wind, atmospheric pressure, and wind waves contribution to the surge formation was assessed. Extreme values of surge heights, which are possible once in a hundred years, were calculated. KEYWORDS: White Sea; Barents Sea; surge; storm surge; ADCIRC; SWAN; unstructured mesh; wind force; atmospheric pressure force; NCEP/CFSR.

Citation: Korablina, A. D., A. T. Kondrin, and V. S. Arkhipkin (2017), Numerical simulations and statistics of surges in the White and Barents seas, Russ. J. Earth. Sci., 17, ES4004, doi:10.2205/2017ES000608.

\section{Introduction}

Surge study on the Arctic Russian coast has a major scientific and practical significance for ensuring the development of shelf natural resources and navigation on the northern sea route. The surge consequences are noticeable in the coastal zone, thus, the surge height calculation is important in the construction of hydraulic structures and port complexes. The research relevance is related to the active development of the Arctic region in recent years, which determines the need to obtain new knowledge about the formation of surges and quantitative assessments of this phenomenon.

Research of the surge level fluctuations in the Barents and White seas has a long history. The results of earlier studies are generalized in monograph [Filatov et al., 2005], and in [Potanin, 1972]. Using the observational data analysis, the average and extreme characteristics of dangerous level rise were calculated. Classification of cyclones causing storm surges was made based on the trajectories of their motion over the Barents and White seas. Variations in the sea level

\footnotetext{
${ }^{1}$ Department of oceanology, Faculty of geography, Lomonosov Moscow State University, Moscow, Russia

Copyright 2017 by the Geophysical Center RAS.

http://elpub.wdcb.ru/journals/rjes/doi/2017ES000608-res.html
}

during the passage of various types of cyclones are considered. In particular, it is shown that deep cyclones passing above the Barents Sea provide a baric wave, which penetrates into the White Sea and induces surges. Estimates of relative contribution of pressure and wind forces to the formation of surges in various synoptic situations are also obtained. However, these results are generally related to the period before the 1980s; therefore, they have to be checked, updated, and significantly upgraded with the new data.

Interaction between surges and tides in the White Sea was investigated using numerical simulations [Belov and Filippov, 1985. Inzhebeykin, 2003. However, the authors of these works used a rather rough orthogonal mesh with a low spatial resolution. Therefore, it is impossible to take into account the influence of the bottom relief and the geometry of the shoreline in the coastal regions, especially, in the bays. In addition, these studies did not evaluate the relative contribution of factors that affect the formation of storm surges, for example, pressure, wind, and waves.

In recent years, the White Sea residual sea level (RSL) fluctuations have been considered in [Kondrin, 2015, 2016 on the basis of a new observational data analysis from four locations: Gorlo, Dvina Bay, Kandalaksha Bay, and the Solovetsky Archipelago. Statistical characteristics of surges in Dvina Bay were investigated in [Korablina et al., 2016].

The main goal of this paper is to propose the applica- 


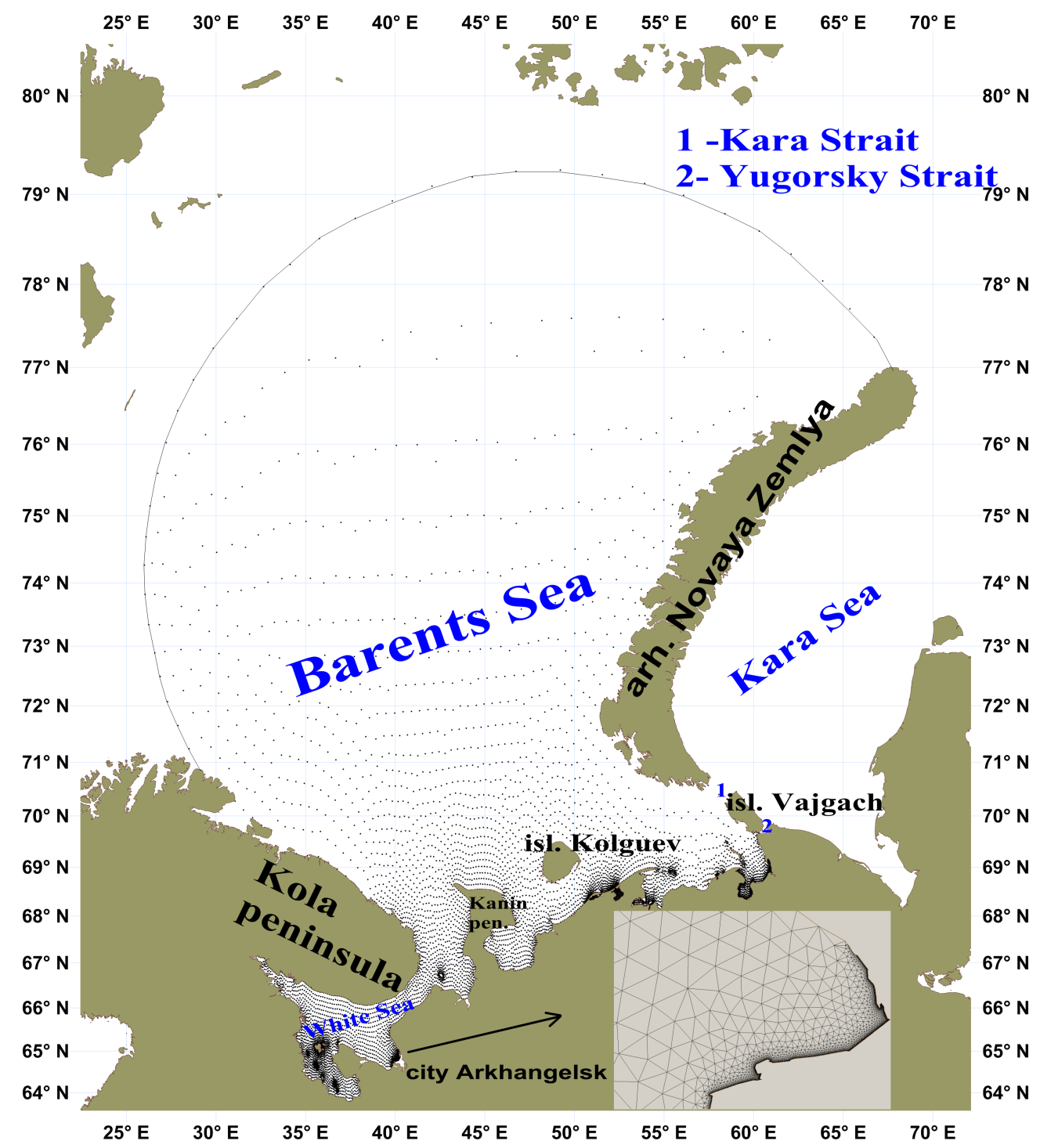

Figure 1. Calculated unstructured mesh for modeling.

tion of a new technique for studying surges. For example, the surge height over a long period of time (1979-2015) was calculated using mathematical modeling taking into account wind, atmospheric pressure, tide, ice concentration, and wind waves. All calculations were carried out on an unstructured mesh, covering both the White and Barents seas. The 37-yr period of observations allowed us to study the seasonal and interannual variability of the surges in the White and Barents seas.

\section{Data and Methods}

Model. In this paper the ADCIRC numerical hydrodynamic model was used to calculate the sea level. A detailed description of the model is given in [Luettich et al., 1992 Lyard et al., 2006. We used the version of the model proposed in [Ivanova et al., 2015, Korablina et al., 2016, 2017. The ADCIRC numerical algorithm model is based on the finite element method, which uses triangular elements and linear basis functions. To assess the contribution of wind waves to sea level formation, a joint ADCIRC + SWAN model was employed which was proposed in [Dietrich et al., 2011]. It combines two well-known and tested models: ADCIRC [Luettich et al., 1992 Luettich and Westerink, Formulation and Numerical Implementation of the 2D/3D ADCIRC Finite Element Model Version44.XX, http://adcirc.org/adcirc_theory_2004_12_08.pdf and SWAN [Booij et al., 1999] Holthuijsen, 2007]. Both ADCIRC and SWAN models are used on an unstructured mesh and adjusted for parallel computations.

Calculation mesh. An unstructured triangulation mesh was created to cover the White and Barents seas using the SMS 11 Aquaveo system [Resio and Westerink, 2008 Figure 1. The mesh was constructed by a paving method 
and consists of 12,715 nodes. The minimum mesh step was $50 \mathrm{~m}$, the maximum was $5 \mathrm{~km}$. We used navigational maps of the following scales: $1: 10,000,1: 25,000,1: 50,000$ to create a digital terrain model. The mesh has two external fluid boundaries: in the Yugor Strait and a semicircular one: from the Kola Peninsula (in the Kirkines area) to Cape Zhelaniya (the Novaya Zemlya Archipelago). The harmonic constants on the semicircular outer boundary were defined by using the FES2004 database with a spatial resolution of $1 / 8^{\circ}$, increments of 1 hour, and full settlement year [Lyard et al., 2006. The open border in the Yugor Strait has the normal wave radiation properties.

Wind, atmospheric pressure, and ice concentration data. Fields of surface wind, atmospheric pressure, and ice concentration from the NCEP/CFSR reanalysis (Climate Forecast System Reanalysis) were set as the input parameters. This is a modern product of the NCEP Center (National Center for Atmospheric Research) implemented in 2010 [Saha et al., 2010]. This NCEP/CFSR reanalysis has a spatial resolution of $\sim 0.3125^{\circ} \times 0.312^{\circ}$; a time step of 1 hour, and covers a period of 32 years from 1979 to 2010. The next version of the NCEP/CFSv2 reanalysis (Climate Forecast System Version 2) with a spatial resolution of $\sim 0.205^{\circ} \times 0.204^{\circ}$ [Saha et al., 2014 and a time resolution of 1 hour was used for numerical calculations from 2011 to 2015. The choice of the CFSR reanalysis is based on [Lindsay et al., 2014, where the comparison between observations at drifting stations and seven reanalysis data are made. Reanalysis of CFSR, MERRA and ERA-Interim have the best correspondence with field observations. The CFSR reanalysis was chosen because its bias error of wind speed at $10 \mathrm{~m}$ is the smallest among others (from 0.0 to -0.3 ). Moreover, the correlation between the CSFR reanalysis data and field observations is quite high; it is within the range from 0.80 to 0.87 during the year [Lindsay et al., 2014]. Evaluation of the quality of the NCEP / CFSR reanalysis for the Barents Sea is given in [Myslenkov et al., 2016].

To analyze the formation of surges using the ADCIRC model, the following tasks were performed:

1. calculation that includes tide, wind field, atmospheric pressure, and ice concentration according to the reanalysis data;

2. calculation that includes tide and ice concentration;

3. calculation that includes tide, wind, and ice field according to the reanalysis data;

4. calculation that includes tide, atmospheric pressure field, and ice concentration according to the reanalysis data.

The surge height is determined by subtracting the tidal oscillations (results of task 2) from the total sea level (results of task 1). Tasks " 3 " and " 4 " are calculated to estimate the contribution of wind and atmospheric pressure to surge formation. Using the joint ADCIRC + SWAN model, the following tasks were performed:

1. calculation that includes tide, wind field, atmospheric pressure, ice according to the reanalysis data;

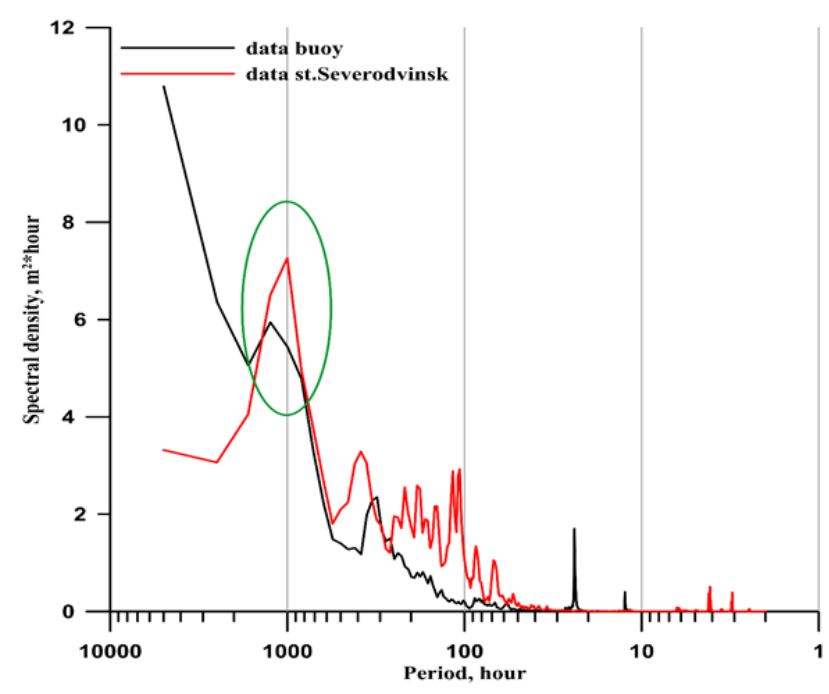

Figure 2. Variations in spectral density $\left(\mathrm{m}^{2} \mathrm{~h}\right)$ according to the hourly level (m) data of the Vardø buoy in 2014 and Severodvinsk station in 2013. (The ellipse separates the peak of the spectral density at a period of $\sim 40$ days).

2. calculation that includes tide, wind field, atmospheric pressure according to the reanalysis data;

3. calculation of task "1" without SWAN.

Tasks " 1 " and " 3 " are calculated to estimate the contribution of wind wave and task " 2 " is calculated to estimate the contribution of ice concentration. Ice is assumed fixed in the model. The SWAN calculation of one step at a time takes much more CPU time using the ADCIRC model. Therefore, the ADCIRC model was used for one year, and the joint model ADCIRC + SWAN was applied only for individual cases of the surge for 4 days (72 hours before the maximum phase of the surge and 24 hours after). The ADCIRC time step was 2 seconds, the SWAN wind wave calculation model was 1200 seconds.

Observation data. Low-frequency sea-level fluctuations were investigated by spectral analysis of the hourly time series of elevation levels obtained from measurements with the Norwegian Vard $\varnothing$ buoy $\left(70.34^{\circ} \mathrm{N}, 31.03^{\circ} \mathrm{E}\right)$ in 2014 in the Barents Sea and at Severodvinsk station (2013) in the White Sea. In both seas, oscillations with a period of about 40 days are distinguished (Figure 2. We analyzed these in situ data due to the fact that we were provided with an hourly updated data at these stations. Then we filtered out the semi-diurnal component of the tide at Severodvinsk station, because its energy is very high.

In this paper, the term "surge" is defined as the rise in the sea level caused by meteorological conditions at the surface, modulated by tides and long-period sea level fluctuations. "Surge" is considered a physical phenomenon. In other words, in order to obtain the surge height, it is necessary to exclude tidal and low-frequency components (seasonal fluctuations and oscillations with a period of 35 to 40 days) from the time series of the total sea level. The 
Table 1. Characteristics of the sea level residual (RSL) fluctuation from observational data and numerical modeling. 1. $\zeta_{O M}(\mathrm{~cm})$ is the maximum deviation of the RSL during the surge according to the observation data. $2 . Z_{M}(\mathrm{~cm})$ is the maximum height of the sea level according to the datum, taking into account the tide. $3 . \zeta_{N M}(\mathrm{~cm})$ is the maximum deviation of the RSL during the surge according to the numerical data. 4. $\gamma=\zeta_{N M} / \zeta_{O M}$ is the ratio of the corresponding maximum heights of the RSL. 5. $\sigma_{\operatorname{modD}} / \sigma_{M}(\mathrm{~cm})$ is the root-mean-square (RMS) error of model calculations i.e. the RMS difference between $\zeta_{O}$ and $\zeta_{N}$ for the decade including the surge (where $\zeta_{O}$ is the deviation of the RSL from the mean value from the observation data, $\zeta_{N}$ is the deviation of the RSL from the mean value from numerical data), $\sigma_{M}$ is the RMS error for the corresponding month. $6 . r_{D} / r_{M}$ is the correlation coefficients between the changes of $\zeta_{O}$ and $\zeta_{N}$ for the decade and month, respectively

\begin{tabular}{lccccccc}
\hline Date & Station & 1 & 2 & 3 & 4 & 5 & 6 \\
\cline { 2 - 7 } & & & & & \\
& & $\zeta_{O M}, \mathrm{~cm}$ & $Z_{M}, \mathrm{~cm}$ & $\zeta_{N M}, \mathrm{~cm}$ & $\gamma$ & $\sigma_{\text {modD }} / \sigma_{M}, \mathrm{~cm}$ & $r_{D} / r_{M}$ \\
\hline November 6, 2010 & Severodvinsk & 96 & 655 & 55 & 0.57 & $18 / 22$ & $0.92 / 0.58$ \\
& Solovki & 61 & 612 & 43 & 0.70 & $15 / 14$ & $0.76 / 0.59$ \\
& Sosnovets & 54 & 748 & 54 & 1.0 & $16 / 17$ & $0.62 / 0.53$ \\
November 15, 2011 & Severodvinsk & 154 & 701 & 107 & 0.69 & $21 / 24$ & $0.97 / 0.85$ \\
& Solovki & 112 & 653 & 90 & 0.80 & $14 / 21$ & $0.95 / 0.78$ \\
November 29, 2013 & Severodvinsk & 81 & 616 & 62 & 0.76 & $20 / 17$ & $0.87 / 0.73$ \\
& Solovki & 56 & 597 & 50 & 0.89 & $14 / 15$ & $0.77 / 0.64$ \\
& Sosnovets & 35 & 653 & 40 & 1.14 & $10 / 13$ & $0.80 / 0.65$ \\
April 23, 2014 & Severodvinsk & 63 & 603 & 45 & 0.71 & $14 / 13$ & $0.80 / 0.77$ \\
& Solovki & 45 & 566 & 32 & 0.71 & $14 / 14$ & $0.65 / 0.55$ \\
May 7, 2014 & Sosnovets & 64 & 645 & 40 & 0.62 & $14 / 18$ & $0.78 / 0.51$ \\
& Severodvinsk & 76 & 598 & 67 & 0.88 & $9 / 16$ & $0.95 / 0.71$ \\
& Solovki & 55 & 557 & 60 & 1.09 & $9 / 14$ & $0.92 / 0.71$ \\
& Sosnovets & 44 & 597 & 48 & 1.09 & $9 / 11$ & $0.81 / 0.70$ \\
\hline
\end{tabular}

new technique for studying surges implies that oscillations with a period of 35 to 40 days are excluded from the time series of the total sea level. Usually the average monthly period is excluded. Thereby, the surge height is determined by subtracting the tidal oscillations (2nd task) from the total sea level (1st task), with the subsequent exclusion of lowfrequency oscillations with the use of the Butterworth digital filter [Otnes and Enokson, 1982]. The term "storm surge" is defined as a surge, the height of which leads to the flooding and the destruction of the shore structures (the surge height may vary from one point to another). "Storm surge" is considered an eco-geographical phenomenon. The height of the "storm surge" is determined at each specific station on the basis of long-term data on floods and extreme sea level. In some cases, the surge height may coincide with the highest level values.

\section{Verification of Model Data Using the Observational Data}

Root-mean-square error (RMSE) for the decade $\sigma_{\operatorname{modD}}$ and for the month, the correlation coefficient $r_{D}$, and the ratio of the maximum heights (observed and model) $\gamma$ were used to assess the quality of the ADCIRC model (see Table 1.

According to the observations made on May 7, 2014 (Figure 3), there was a significant surge. The surge heights at the following stations were: Severodvinsk $0.76 \mathrm{~m}$, Solovki
$0.55 \mathrm{~m}$, Sosnovets $0.44 \mathrm{~m}$. At Severodvinsk station the maximum deviation of the surge height occurred at 06:00 on May 7 and was $0.67 \mathrm{~m}$ (model data), with the underestimation of the level in the model being $\gamma=0.88$. The maximum increase in surge level fluctuations at Solovki station occurred later around 09:00. According to the observations and the model, the height of the surge was approximately the same and amounted to $0.55 \mathrm{~m}$ and $0.60 \mathrm{~m}$, respectively with the ratio $\gamma=1.09$. Thus, in Severodvinsk the correlation coefficient for the period from 1 to 10 May was 0.95 , and the RMSE was $0.09 \mathrm{~m}$. Analysis of the two other stations showed a similar result. For example, at Sosnovets station the $r_{D}$ and RMSE were 0.81 and $0.09 \mathrm{~m}$, respectively, at Solovki station $r_{D}=0.92$ and $\sigma_{\operatorname{modD}}=0.09 \mathrm{~m}$. Thus, the simulation of the surge that occurred on May 7, 2014 in the White Sea reflects quite accurately the surge height.

Analysis of the model and observation data during the five surges that occurred on May 7 and April 23-24, 2014, November 29, 2013, November 15, 2011, and November 6, 2010, showed that the ADCIRC model quite satisfactorily reflects the height of the surges. These verification dates were chosen due to significant level increases at these stations. This is confirmed by high values of the correlation coefficient for decadal time series of model $r_{D}$ and observation data. At Severodvinsk station $r_{D}$ is in the range from 0.87 to 0.97 , with the RMSE $\sigma_{\text {modD }}$ ranging from $0.09 \mathrm{~m}$ to $0.21 \mathrm{~m}$ (maximum with a height difference of more than $1.70 \mathrm{~m}$ on November 15, 2011); at Solovki station $r_{D}=0.65 \div 0.95$, with $\sigma_{\operatorname{modD}}=0.09 \mathrm{~m} \div 0.15 \mathrm{~m}$; at the station Sosnovets $r_{D}=0.62 \div 0.81$, with $\sigma_{\operatorname{modD}}=0.09 \mathrm{~m} \div 0.16 \mathrm{~m}$. More- 

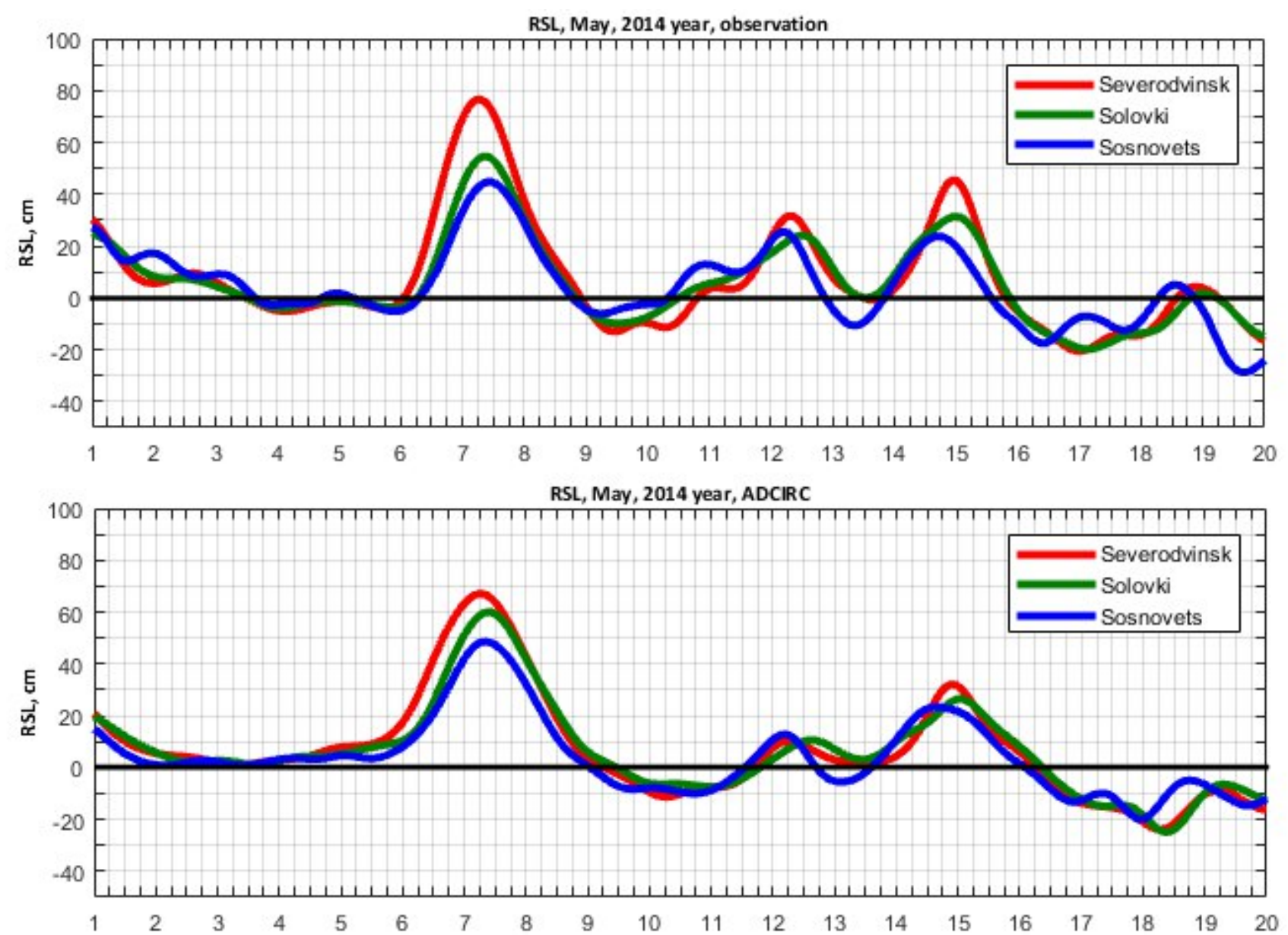

Figure 3. Residual sea level (RSL, cm) in May 2014 according to numerical calculations (bottom panel) and observational data (top panel) at the points: Severodvinsk, Solovki, and Sosnovets. RSL was obtained by excluding tidal and low-frequency components from the total level.

over, in May 2014 the value of the RMSE was minimal at all three stations and reached $0.09 \mathrm{~m}$, and the correlation coefficient for the decade varied from 0.81 (Sosnovets) to 0.95 (Severodvinsk).

The correlation coefficient $r_{D}$ calculated for the decade is substantially higher at all three points than the coefficient calculated for the whole month. This means that the model reproduces the height of the surge well enough during the time of the surge itself. The data of the ADCIRC model understates the height of the surge at Severodvinsk station where the ratio of maximum heights (model and observed) is $\gamma=0.57 \div 0.88$. Consequently, the model needs some refinement of the parameters, in particular, wind speed and wind waves, which were not taken into account here. Perhaps, the increase in the accuracy of model data is associated with the need to fine-tune the geometry of the shoreline and bathymetry, as well as the quality of the CFSR reanalysis data. Comparison of simulation results with actual data showed that ADCIRC reliably reproduces the position of the level in space and time.

\section{Analysis and Statistics of the Model Data}

Contribution of the surge height to the total sea level. In this paper, as it was mentioned earlier, the term "surge" is defined as the rise in the sea level caused by meteorological conditions at the surface, modulated by tides and long-period sea level fluctuations. The height of the surge is determined by eliminating tidal and low-frequency components (seasonal fluctuations and natural oscillations of the basin with a period of 35-40 days) from the total sea level [Korablina et al., 2017]. In some cases, the height of the surge may coincide with the highest level values. Rarely, but still there are some cases, when the negative or insignificant height of the surge remains after applying the technique of exclusion of oscillations. Such a case will be regarded in this paper as "surge", but not "storm surge". This allows us to understand the physical causes for the formation of the "surge" when we consider only surge. "Storm surge" is formed due to a variety of causes. We cannot always distin- 
guish what was the main cause of the surge formation. The term "storm surge" should be defined as surge, the height of which leads to the flooding and destruction of shore structures, hence, the height of the "storm surge" is determined at each specific point on the basis of floods and extreme sea level long-term data. Now in the work the term "surge" should be attributed to the oceanographic nature, and the "storm surge" to the eco-geographical one. The contribution of surge height to the total sea level was estimated on the basis of the data obtained from the ADCIRC model.

The contribution of the surge height to the total sea level was calculated by using module (absolute value of a number). Therefore, there are also cases when the total sea level is negative (this happens when the surge falls on the low tide phase). The largest number of surges in this range $(\geq 100 \%)$ was recorded at all stations except for Severodvinsk, Onega Bay, and Khaypudyr Bay. At these stations the greatest contribution to the White Sea is recorded in the range from 55 to $74 \%$. While $36 \%$ of the total number of surges (39 surges) at the station in Severodvinsk fell in that range, and $42 \%$ (71 cases) at the station in Onega Bay. In Khaypudyr Bay, $38 \%$ of the total number of surges (78 cases of 207) contribute from 75 to $99 \%$ to the total sea level. More than half of all analyzed surges add over $55 \%$ of the contribution to the total sea level. At three stations, the contribution of the surge height to the total sea level is less than $54 \%$ to the total sea level: $13 \%$ of the total number of surges (26 cases) were within that range at Solovki station, $24 \%$ (41 cases) in Onega Bay, 35\% (41 events) in Chyosha Bay, 3\% (3 surges) at Severodvinsk station.

Based on the quantitative characteristics of the considered surges and the contribution of the surge height to the total sea level, according to the model data, it is possible to accept the critical marks of the surge value (if exceeded, there is a high likelihood of the adjacent territories being flooded). At the points under study, the critical values of the surge heights are the following: more than $0.3 \mathrm{~m}$ for Solovki station, more than $0.5 \mathrm{~m}$ for Onega Bay and Severodvinsk, more than $0.7 \mathrm{~m}$ for Pechora Bay, more than $0.8 \mathrm{~m}$ for Chyosha Bay, and more than $1.0 \mathrm{~m}$ for Varandey and Khaypudyr Bay (see
Table 21. The maximum surge height, possible once in a hundred years, was calculated on the basis of model data. In the White Sea the heights were $1.0 \mathrm{~m}$ (in Solovki), $1.3 \mathrm{~m}$ (in Severodvinsk), $1.9 \mathrm{~m}$ (in Onega Bay); in the Barents Sea the heights were $2.3 \mathrm{~m}$ (in Chyosha and Pechora Bay), $3.7 \mathrm{~m}$ (in Varandey), $4.9 \mathrm{~m}$ (in Khaypudyr Bay).

Seasonal and interannual variability of surges. Data were analyzed at the following six points: Solovki $\left(35.67^{\circ} \mathrm{E}, \quad 65.01^{\circ} \mathrm{N}\right)$, Onega Bay $\left(37.75^{\circ} \mathrm{E}, \quad 63.95^{\circ} \mathrm{N}\right)$, Severodvinsk $\left(39.76^{\circ} \mathrm{E}, 64.62^{\circ} \mathrm{N}\right)$ in the White Sea; Chyosha Bay $\left(47.59^{\circ} \mathrm{E}, 67.06^{\circ} \mathrm{N}\right)$, Pechora Bay $\left(54.50^{\circ} \mathrm{E}, 68.60^{\circ} \mathrm{N}\right)$, Varandey $\left(57.97^{\circ} \mathrm{E}, 68.80^{\circ} \mathrm{N}\right)$, Khaypudyr Bay $\left(59.86^{\circ} \mathrm{E}\right.$, $68.45^{\circ} \mathrm{N}$ ) in the Barents Sea. First, all surges above $0.3 \mathrm{~m}$ were spread over heights. In the White Sea the surges of 0.9-1.2 $\mathrm{m}$ account only for $1 \%$ of all surges (according to 3 stations), and the maximum number of the surges of this height was found in Onega Bay (10). Maximum height in the range from 0.3 to $0.6 \mathrm{~m}$ forms $88 \%$ with 462 cases recorded in Onega Bay, 409 (cases) in Severodvinsk, and 192 (cases) in Solovki. In the Barents Sea $3 \%$ of all surges have the height exceeding $1.2 \mathrm{~m}$. For example, 7 cases were recorded in Pechora Bay, 14 in Chyosha Bay, 34 in Varandey, 106 in Khaypudyr Bay. Here, surges of 0.9-1.2 m height account for $6 \%$ of the total quantity and surges of $0.6-0.9 \mathrm{~m}$ height account for $22 \%$. The largest number of surges is characterized by height value of $0.3-0.6 \mathrm{~m}(69 \%)$, with the largest number of surges in all heights ranges in Khaypudyr Bay (1143 surges).

Using the numerical modeling data, the distribution of the number of surges in percentage by months for 1979-2015 was obtained from the six points described above (Figure 4). The months with the smallest and largest number of surges are clearly marked in the White Sea: July (1-3\%) and October (Solovki $-16 \%$, Severodvinsk $-13 \%$ ), respectively. The exception is Onega Bay where the maximum surges number is observed in November $(13 \%)$. The second small maximum $(11-12 \%)$ is found in February. In the Barents Sea the smallest number of surges is observed in July-August (5\%) $(6 \%$ in Khaypudyr Bay), and the maximum number is observed in

Table 2. The number of surges (in brackets in percent) and the contribution of the surge height to the total sea level in percent (\%) according to numerical modeling data for 1979-2015

Points Surge height, $\mathrm{m}$ Total surge numbers $\quad$ Contribution of surge height to the total sea level, $\%$

$\leq 54 \% \quad 55-74 \quad 75-99 \quad \geq 100 \%$

\begin{tabular}{llccccc}
\hline & \multicolumn{5}{c}{ White Sea } \\
Solovki & $\leq 0.3$ & 196 & $26(13)$ & $40(20)$ & $28(14)$ & $102(53)$ \\
Onega Bay & $\leq 0.5$ & 171 & $41(24)$ & $71(42)$ & $3(1)$ & $56(33)$ \\
Severodvinsk & $\leq 0.5$ & 107 & $3(3)$ & $39(36)$ & $38(36)$ & $27(25)$ \\
& & \multicolumn{5}{c}{ Barents Sea } \\
Pechora Bay & $\leq 0.7$ & 103 & & & & \\
Chyosha Bay & $\leq 0.8$ & 117 & $41(35)$ & $9(8)$ & $45(44)$ & $36(35)$ \\
Varandey & $\leq 1.0$ & 76 & & $15(20)$ & $26(34)$ & $61(52)$ \\
Khaypudyr Bay & $\leq 1.0$ & 207 & & $53(25)$ & $78(38)$ & $76(36)$ \\
\hline
\end{tabular}




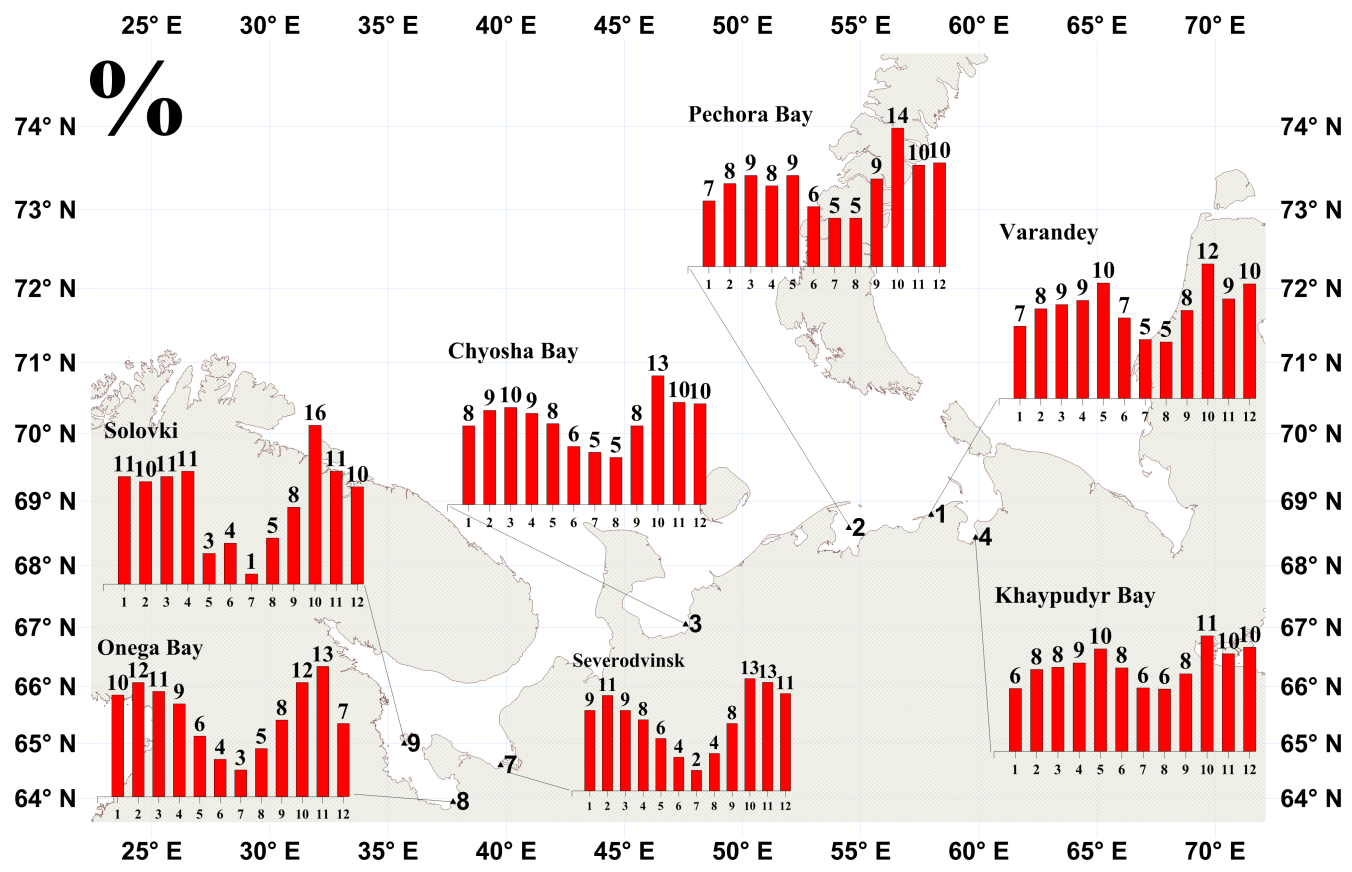

Figure 4. The variability of surges by month (\%) for the period 1979-2015.

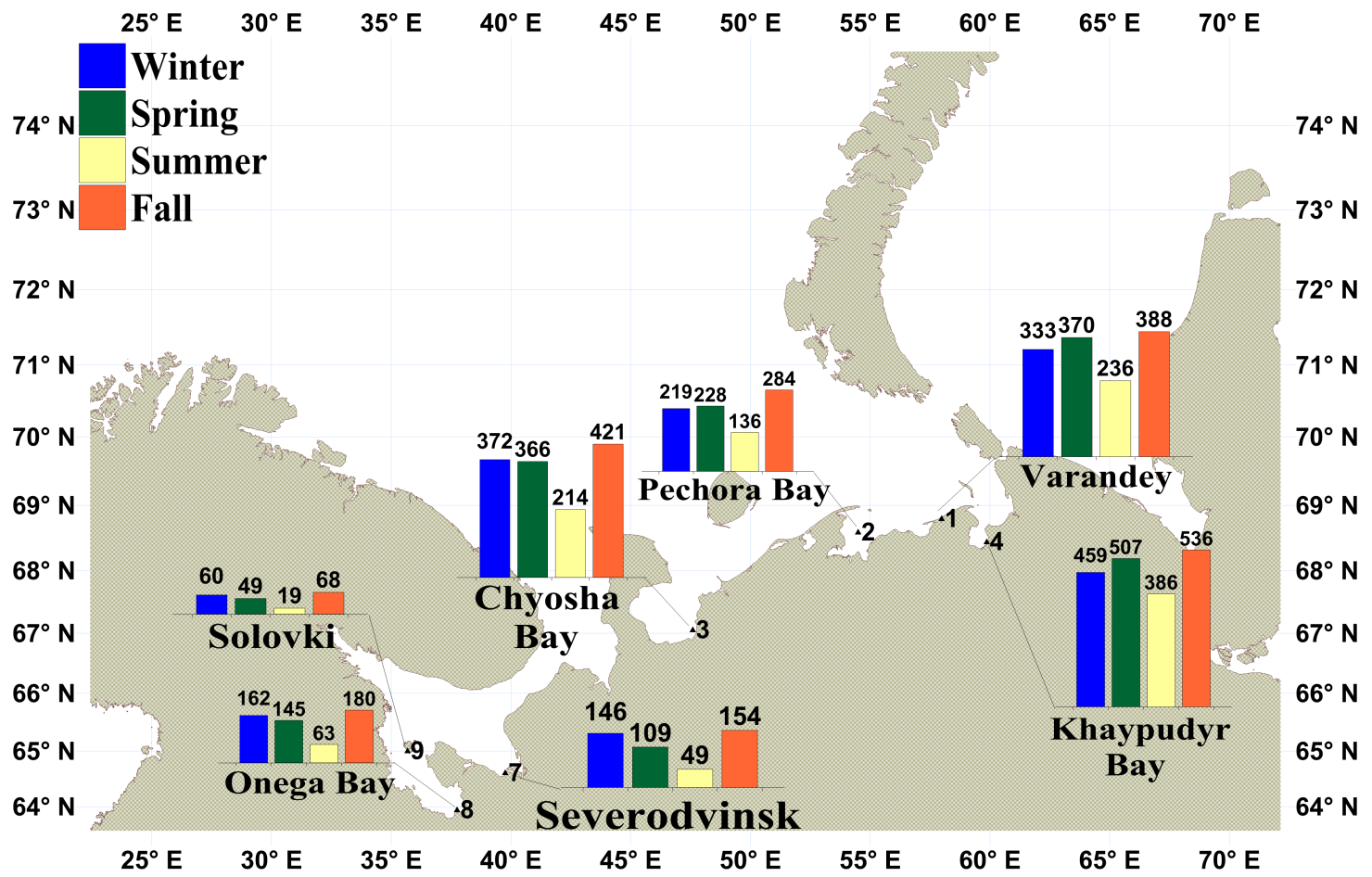

Figure 5. The number of surges by season (winter: December, January, February, etc.) for the period $1979-2015$.

October (KhaipudyrBay - 11\%, Varandey - 12\%, Chyosha Bay $-13 \%$, Pechora Bay - 14\%). In Khaypudyr Bay there is a fairly uniform distribution of the occurrence of surges which varies from 6 to $11 \%$ by months throughout the year. Figure 5 shows the distribution of the number of surges by season (winter: December, January, February, etc.) for the period 1979-2015. The minimum number of surges is formed in summer, both in the White and Barents seas, for example, Solovki - 19, Severodvinsk - 49, Onega Bay - 63, Pechora Bay - 136, Chyosha Bay - 214, Varandey - 236, 
Khaypudyr Bay - 386. In both seas maximum number of surges was recorded in fall period: Solovki - 68, Severodvinsk - 154, Onega Bay - 180, Pechora Bay - 284, Chyosha Bay - 421, Varandey - 388, Khaypudyr Bay - 536. The second maximum is formed in the White Sea in winter, and in the Barents Sea - in spring, except for Chyosha Bay.

Such seasonal variability of surges is associated with the position of the White Sea. Arctic air masses dominate over the northern part of the sea and the air masses of mid-latitudes are located over the southern part of the sea. The Arctic front is formed at the border of these two main streams. Here cyclones and anticyclones are formed.

The Icelandic Low deepens in winter. Then the Arctic front is strengthened due to the interaction between the Icelandic Low and the Siberian High. This leads to cyclonic activity over the center of the Barents Sea. At this time, the southwestern winds dominate. Northeastern winds are observed over the northwestern part of the Barents Sea (in its shallow part), and southeastern winds are localized over the southeastern part of the Barents Sea.

Contribution of the atmospheric pressure, wind stress, wind waves, and ice concentration to the surge height formation. The analysis of the contribution of the atmospheric pressure and wind stress to the surge height formation showed that the greatest number of surges is formed under the influence of wind stress (a contribution of more than $75 \%$ ) at all stations except Severodvinsk, Chyosha Bay, and Pechora Bay, where the wind contribution is $55-75 \%$ (Figure 6 ). The number of surges, for which the atmospheric pressure contribution to their formation is more than 55\%, is as follows: in Solovki 3\% (of the total number), in Onega Bay 6\%, in Severodvinsk - 8\%, in Varandey and Khaypudyr Bay - 9\%, in Chyosha Bay - 10\%, in Pechora Bay $-11 \%$. Moreover, $3 \%$ of all surges in Khaypudyr Bay are formed only by the atmospheric pressure (more than $75 \%$ ).

The influence of the wind waves and ice concentration (in winter months) were estimated for the surges in Varandey, Pechora Bay, and Khaypudyr Bay (see Table 3). The wind waves raise the sea level up to $5 \%$ (approx. $10 \mathrm{~cm}$ ), and lack of ice cover can increase level up to $2-5 \%$ (up to $8 \mathrm{~cm}$ ). Model calculations of the contribution of the wind waves and ice cover to the surge formation at three stations in the White Sea did not show any distinctive results. This might be attributed to the following. Most of the surges in the White Sea are due to the arrival of the Barents Sea wave through the Voronka into the White Sea Basin. Wind wave data in the White Sea show that strong wind waves do not reach the coast of Dvina and Onega bays [Arkhipkin et $a l ., 2015$. Our reference stations are located in tidal drying zones with mobile fast ice, which experiences the greatest deformation. Mobile fast ice is characterized by the presence of a large number of cracks of various directions and extent. From the so-called immobile fast ice it is separated by tidal cracks, which are parallel to the coast. It is established that during the surge the mobile fast ice breaks away from the coast, which is often observed in the White Sea, and on the other coasts of the tidal seas of the Arctic Ocean [Romanenko et al., 2013. Therefore, estimations of the contribution of wind waves and ice cover to the formation of surges in the
Table 3. Sea level (m) model data at Varandey, Pechora Bay, and Khaypudyr Bay stations during surges, calculated using ADCIRC + SWAN to estimate the contribution of the wind waves and ice cover to the surge formation

\begin{tabular}{|c|c|c|c|}
\hline $\begin{array}{l}\text { Date, } \\
\text { time } \\
\text { (UTC) }\end{array}$ & $\begin{array}{l}\text { Without } \\
\text { SWAN } \\
\text { (sea } \\
\text { level, m }\end{array}$ & $\begin{array}{c}\text { ADCIRC } \\
+ \text { SWAN } \\
\text { (sea } \\
\text { level, m }\end{array}$ & $\begin{array}{c}\text { ADCIRC } \\
+ \text { SWAN } \\
\text { without ice } \\
\text { (sea } \\
\text { level, m) }\end{array}$ \\
\hline \multicolumn{4}{|c|}{ Varandey } \\
\hline 27.01.2010, 06:00 & 2.13 & 2.15 & 2.23 \\
\hline $25.04 .2010,19: 00$ & 1.77 & 1.78 & \\
\hline $24.07 .2010,06: 00$ & 3.46 & 3.58 & \\
\hline $17.08 .2010,02: 00$ & 2.14 & 2.20 & \\
\hline $18.11 .2010,15: 00$ & 2.12 & 2.22 & 2.21 \\
\hline $02.12 .2010,22: 00$ & 1.83 & 1.84 & 1.87 \\
\hline \multicolumn{4}{|c|}{ Pechora Bay } \\
\hline 27.01.2010, 12:00 & 1.02 & 1.04 & 1.11 \\
\hline $25.04 .2010,23: 00$ & 1.24 & 1.25 & 1.27 \\
\hline 24.07.2010, 09:00 & 1.73 & 1.87 & \\
\hline 17.08.2010, 03:00 & 1.39 & 1.48 & \\
\hline 18.11.2010, 20:00 & 1.30 & 1.38 & \\
\hline $3.12 .2010,09: 00$ & 1.16 & 1.20 & \\
\hline \multicolumn{4}{|c|}{ Khaypudyr Bay } \\
\hline $27.01 .2010,12: 00$ & 2.30 & 2.31 & 2.36 \\
\hline 26.04.2010, 02:00 & 1.90 & 1.90 & 1.90 \\
\hline $24.07 .2010,11: 00$ & 4.04 & 4.11 & \\
\hline 17.08.2010, 06:00 & 1.99 & 2.02 & \\
\hline 18.11.2010, 20:00 & 2.24 & 2.25 & \\
\hline
\end{tabular}

White Sea differ only at the level of a systematic error or less. However, this number of calculations is not sufficient to fully assess the impact of wind waves and ice cover on sea level.

For the analysis of the synoptic situations during surges, the classification was used as described in [Potanin, 1972 All cases for Severodvinsk with height exceeding $0.5 \mathrm{~m}$ were chosen and cases with height more than $1.0 \mathrm{~m}$ were selected for Varandey for the analysis of surges Table 4. In the period from 1979 to 2015, 76 cases were identified for Severodvinsk and 107 for Varandey. In Severodvinsk $47 \%$ of the surges were formed after the passage of deep "diving" cyclones and $63 \%$ in Varanday, respectively. Moreover, in any case the surges in Varandey were formed under the influence of the western wind and the maximum average level of $1.63 \mathrm{~m}$ was formed after the passage of western cyclones. The formation of surge in the White Sea, where the Barents Sea surge wave is transformed under the influence of local wind, bottom relief, and the shoreline geometry, had a more complicated structure [Korablina et al., 2017]. The surges that occur due to the passage of the "diving" cyclones are characterized by the largest average height of $0.64 \mathrm{~m}$.

Model data allowed us to estimate the interannual variability of surges for the period 1979-2015. In the White Sea 


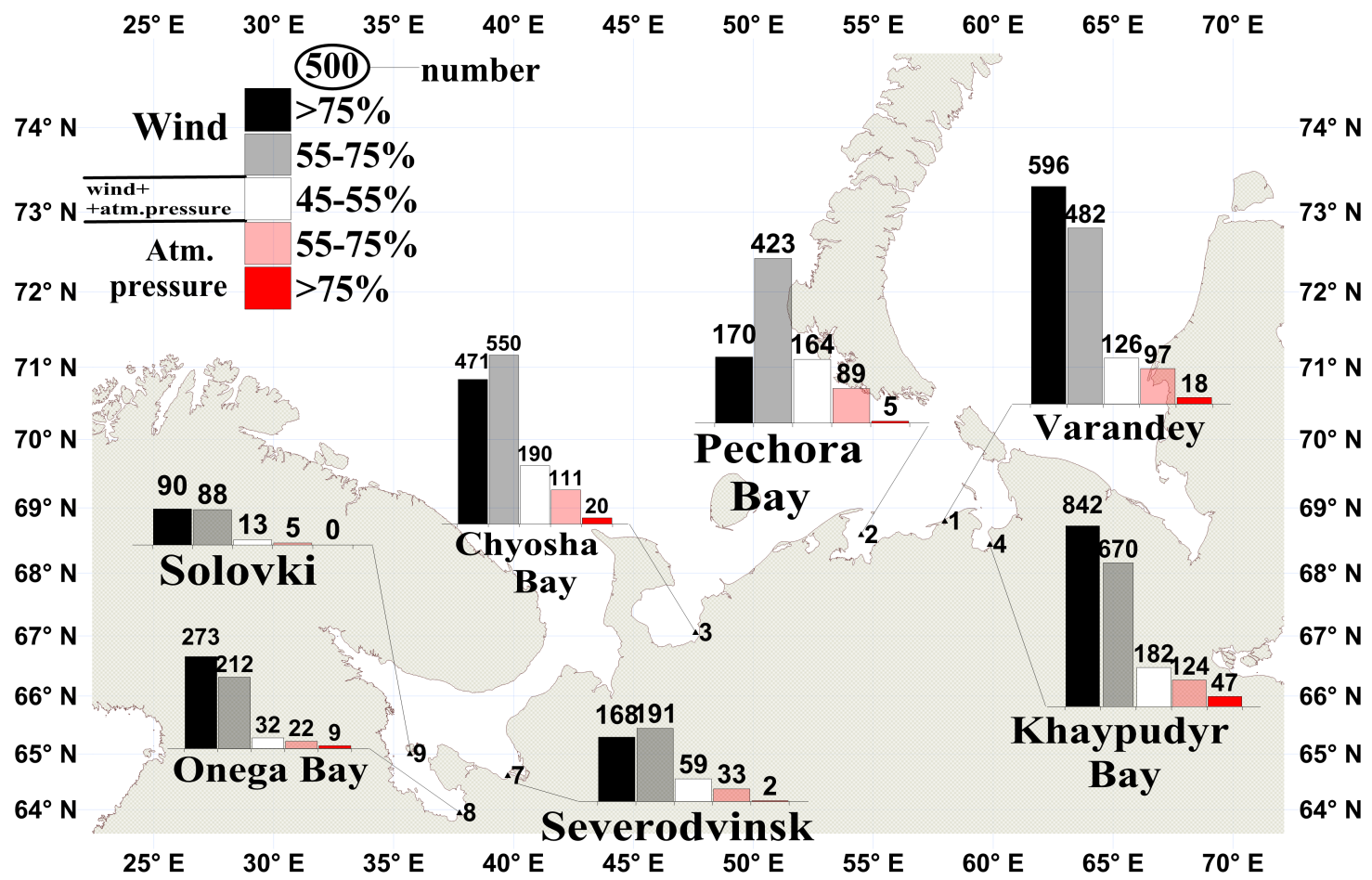

Figure 6. Number of surges versus contribution of wind and atmospheric pressure (percentage) to the surge formation.

Figure 7), according to three points (Solovki, Dvina Bay, Onega Bay), a similar pattern was observed in the distribution of the number of surges during the period under research. According to the running moving average by 5 -years increments in Dvina and Onega Bays and at Solovki station, the minimum number of surges occurred in 1982, 1998, 2010 and the maximum number of surges was recorded in 1993, 2003, and 2013. In Solovki the number of surges per year was in the range from 1 to 9, and in Dvina Bay and Onega Bay from 5 to 20, respectively. In the Barents Sea Figure 8 the minimum occurred in 1985, 2000, 2007, and 2010. According to the data in Pechora Bay, Varandey, Khaypudyr Bay, and Chyosha Bay, the maximum number of surges was in 1983, 1990, and 2005. In Pechora Bay from 15 to 36 surges were recorded each year, which is less than in Varandey and Chyosha Bay, where the number of surges was in the range from 24 to 53 per year. The largest number of surges was observed in Onega Bay (the White Sea) and in Khaypudyr Bay (the Barents Sea).

\section{Conclusions}

The ADCIRC model quite satisfactorily reproduces RSL fluctuations during surges. This conclusion is based on the high values of the correlation coefficient for the ten-day time series during the surge (0.80-0.97 in Severodvinsk). Moreover, the RMSE of the model calculations is relatively small for such time intervals (in Severodvinsk the maximum value is $21 \mathrm{~cm}$ with the RSL difference on November 15, 2011 more than $170 \mathrm{~cm}$ ). In May 2014, the RMSE value was minimal at all three points and equal to $9 \mathrm{~cm}$. At the same time the correlation coefficient ranged from 0.81 in Sosnovets to 0.95 in Severodvinsk.

In this paper, a new method of calculating surge height is presented. It is proposed to divide the term "surge" and "storm surge". Numerical simulation data allowed us to study surges over an extended period of time from 1979 to 2015. The contribution of the surge height was more than $55 \%$ of the total sea level. A smaller contribution was found in Solovki (13\%), in Onega Bay (24\%), in Chyosha Bay $(35 \%)$, and in Severodvinsk $(3 \%)$. In this regard, the following critical values of surge heights are proposed: for Solovki station more than $0.3 \mathrm{~m}$, for Onega Bay and Severodvinsk more than $0.5 \mathrm{~m}$, for Pechora Bay more than $0.7 \mathrm{~m}$, for Chyosha Bay more than $0.8 \mathrm{~m}$, for Varandey and Khaypudyr Bay more than $1.0 \mathrm{~m}$. It was established on the basis of modeling that in the White Sea the share of surges of 0.9 $1.2 \mathrm{~m}$ height was $1 \%$ of the total number in 37 years. In the Barents Sea the surges with a height more than $1.2 \mathrm{~m}$ constituted $3 \%$ and surges of $0.9-1.2 \mathrm{~m}$ height constituted $6 \%$ of the total number of surges for the same time period. The largest number of surges is formed in Khaypudyr Bay. In both seas, the smallest number of surges is formed in JulyAugust; the largest is formed in October. Such seasonal variability is associated with the intensification of cyclonic activity at the Arctic front. In the cold season, the Arctic 


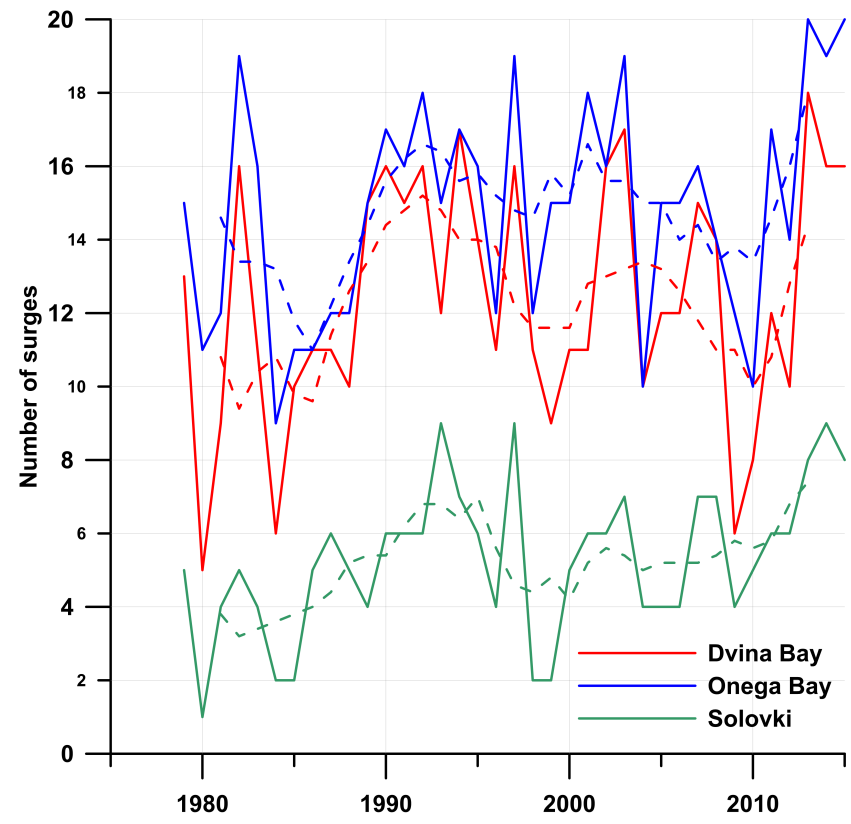

Figure 7. Long-term variability of the occurrences of surges $(>0.3 \mathrm{~m})$ in the White Sea (dashed line denotes running average with a step of 5 years) for the period 1979-2015.

front intensifies while passing over the Barents Sea and then shifts to the south.

For the first time, the contributions of wind, atmospheric pressure, wind waves, and ice concentration to surges formation were calculated separately. The surges, which are formed only by the atmospheric pressure, are several times smaller than the surges that are formed under the influence

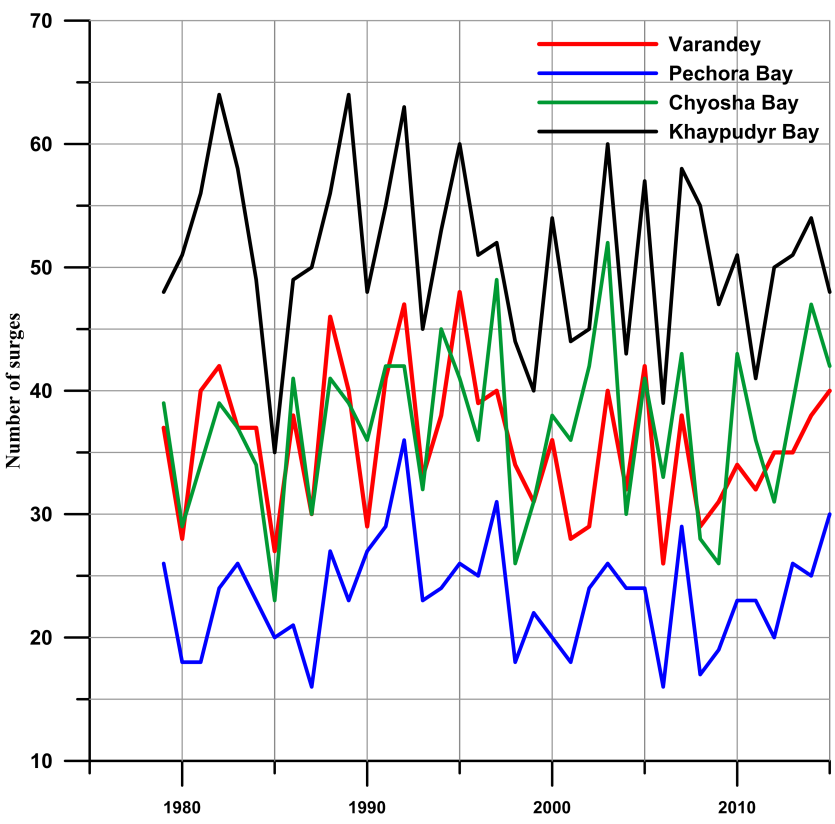

Figure 8. Long-term variability of the occurrences of surges $(>0.3 \mathrm{~m})$ in the Barents Sea for the period 1979-2015.
Table 4. Characteristics of the storm surges in the White and Barents seas depending on the cyclone trajectory. Column 1 shows the number of surges (\%), column 2 is average surge height $(\mathrm{m})$, column 3 is the average wind direction $\left(^{\circ}\right)$ six hours before the surge reaches the maximum

\begin{tabular}{lccc}
\hline Cyclone trajectories (in the White Sea) & 1 & 2 & 3 \\
\hline Anomalous & 11 & 0.59 & 113 \\
Western with a center over the White Sea & 21 & 0.60 & 116 \\
Western with a center over the Barents Sea & 12 & 0.63 & 193 \\
"Diving" & 47 & 0.64 & 152 \\
Southern & 9 & 0.54 & 161 \\
\hline
\end{tabular}

Cyclone trajectories (in the Barents Sea)

\begin{tabular}{llll}
\hline Anomalous & 16 & 1.22 & 278 \\
Western & 21 & 1.26 & 265 \\
"Diving" & 63 & 1.23 & 276
\end{tabular}

of wind component. Onega Bay, Khaypudyr Bay, Varandey are the stations where the surge was mainly formed under the wind influence (the wind impact is more than $75 \%$ ). Wind waves raise the sea level to $10 \mathrm{~cm}$, and lack of the ice cover can increase level up to $8 \mathrm{~cm}$. In the White Sea, the contribution of wind waves and ice cover is not significant in view of the specifics of the wind climate and fast ice at the coast.

Acknowledgments. The study was supported by the Russian Science Foundation (grant No. 14-37-00038).

\section{References}

Arkhipkin, V. S., S. A. Dobrolyubov, S. A. Myslenkov, A. D. Korablina (2015), Wave climate of the White Sea, Changing Climate and Socio-Economic Potential of the Russian Arctic, S. A. Sokratov (Ed.), Vol. 1 p. 48-58, Liga-Vent, Moscow. (in Russian)

Belov, V. P., Y. G. Filippov (1985), Numerical modeling of total fluctuations in the level of the White Sea, Meteorology and Hydrology, No. 7, 63-69. (in Russian)

Booij, N., R. C. Ris, L. H. Holthuijsen (1999), A thirdgeneration wave model for coastal regions. Model description and validation, J. Geophys. Res., 104, No. C4, 7649-7666.

Dietrich, J. C., et al. (2011), Modeling Hurricane Waves and Storm Surge using Integrally-Coupled, Scalable Computations, Coastal Engineering, 58, No. 1, 45-65.

Filatov, N., et al. Filatov, N., (2005), White Sea its Marine Environment and Ecosystem Dynamics Influenced by Global Change, 472 pp., Springer-Praxis, UK.

Holthuijsen, L. H. (2007), Waves in Oceanic and Coastal Waters, 387 pp., Cambridge University Press, Cambridge.

Inzhebejkin, Y. I. (2003), Level fluctuations in the White Sea, 152 pp., UrO RAN, Ekaterinburg. (in Russian)

Ivanova, A. A., et al. (2015), Storm surges modeling in the coastal zone of Sakhalin island, Moscow University Bulletin. Series 5. Geography, No. 3, 41-49. (in Russian)

Kondrin, A. T. (2015), Storm surges in the area of the MSU White Sea Biological Station, Moscow University Bulletin. Series 5. Geography, No. 6, 96-107. (in Russian) 
Kondrin, A. T. (2016), Storm surge formation in the White Sea, Moscow University Bulletin. Series 5. Geography, No. 6 , 33-40. (in Russian)

Korablina, A. D., V. S. Arkhipkin, T. V. Samborskiy (2016), Features of the formation of storm surges in the dynamic system The White Sea - the mouth area of the river Northern Dvina, Moscow University Bulletin. Series 5. Geography, No. 1, 78-86. (in Russian)

Korablina, A. D., A. T. Kondrin, V. S. Arkhipkin (2017), Simulation of surges in the White and Barents Seas for the period 1979-2015, Proceedings of the Hydrometcentre of Russia, No. 364, 144-158. (in Russian)

Lindsay, R., M. Wensnahan, A. Schweiger, J. Zhang (2014), Evaluation of Seven Different Atmospheric Reanalysis Products in the Arctic, J. of Climate, 27, 2588-2606 doi:10.1175/JCLID-13-00014.1

Luettich, R. A., J. J. Westerink, N. W. Scheffner (1992), ADCIRC: an advanced three-dimensional circulation model for shelves coasts and estuaries, report 1: Theory and methodology of $A D C I R C$-2DDI and ADCIRC-3DL, Dredging Research Program Technical Report DRP-92-6, U.S., 137 pp., Army Engineers Waterways Experiment Station, Vicksburg, MS.

Lyard, F., F. Lefévre, T. Letellier, O. Francis (2006), Modelling the global ocean tides: a modern insight from FES2004, Ocean Dynamics, No. 56, 394-415.
Myslenkov, S. A., P. A. Golubkin, E. V. Zabolotskikh (2016), Evaluation of wave disturbance modeling in the Barents Sea during the passage of the winter cyclone, Moscow University Bulletin. Series 5. Geography, No. 6, 26-32. (in Russian)

Otnes, R., L. Enokson (1982), Applied analysis of time series. Basic methods, 432 pp., Mir, Moscow. (in Russian)

Potanin, V. A. (1972), Formation and damping of Barents Sea and White Sea storm surges, Questions of oceanology and complex research of the shelf of the Barents and the White Seas p. 11-14, Apatity, RF. (in Russian)

Resio, D. T., J. J. Westerink (2008), Modelling the physics of storm surges, Physics Today, 61, No. 9, 33-38.

Romanenko, F. A., et al. (2013), Life of the White Sea fast ice, Priroda, No. 2, 97-101. (in Russian)

Saha, S., et al. (2010), The NCEP Climate Forecast System Reanalysis, Bull. Amer. Meteor. Soc., 91, No. 8, 1015-1057. Saha, S., et al. (2014), The NCEP Climate Forecast System Version 2, J. Climate, 27, 2185-2208 doi:10.1175/JCLI-D12-00823.1

V. S. Arkhipkin, A. T. Kondrin, and A. D. Korablina, Department of oceanology, Faculty of geography, Lomonosov Moscow State University, Moscow, Russia. (jacksparrow91@bk.ru) 